Article

\title{
Application of the Mesohabitat Simulation System (MesoHABSIM) for Assessing Impact of River Maintenance and Restoration Measures
}

\author{
Katarzyna Suska *D and Piotr Parasiewicz \\ Stanislaw Sakowicz Inland Fisheries Institute, Oczapowskiego Street 10, 10-719 Olsztyn, Poland; \\ riverpiotr@gmail.com \\ * Correspondence: k.suska@infish.com.pl
}

Received: 13 October 2020; Accepted: 27 November 2020; Published: 30 November 2020

\begin{abstract}
Maintenance and restoration activities alter the river morphology and hydrology, and in consequence, alter fish habitats. The aim of this research was to investigate the change of habitat availability for fish guilds after carrying out maintenance works, commonly used river restoration measures and a restoration derived from fish habitat requirements. The selected study site is located at a close to natural condition section of Swider River in central Poland. The MesoHABSIM model was used to assess the area of suitable habitats in this site and predict habitat distribution at all planning scenarios. The affinity index which is a measure of similarity of two distributions showed that the likely distribution of habitats for fish resulting from simulated maintenance is $76.5 \%$ similar to that under measured conditions. The distribution of habitats caused by river restoration is also similar to that of the baseline in $73.2 \%$. The resemblance between the restoration scenario focusing on fish habitat requirements and the reference conditions is $93.1 \%$. It is beneficial to define the river restoration measures based on habitat availability for fish community. Modelling is a useful tool to simulate the changes and predict which guilds there is abundance of suitable habitats, and for which there are too few. It allows for more effective use of resources according to quantitative target states.
\end{abstract}

Keywords: MesoHABSIM; fish; river restoration; restoration; maintenance works; simulations; hydromorphology; habitat; Poland

\section{Introduction}

All Member States of the EU must comply with the requirements of the Council Directive concerning the protection of waters against pollution, caused by nitrates from agricultural sources [1] and Water Framework Directive [2]. Despite the legislative tools introduced, in the second River Basin Management Plans $60 \%$ of the surface water bodies in EU did not achieve good ecological status and $46 \%$ did not achieve good chemical status (the status of $16 \%$ is unknown). The main stressors are hydromorphological pressures (40\%), diffuse pollution sources (38\%) from agriculture and atmospheric deposition, followed by point source pollution (18\%) and water abstraction (7\%) [3]. Hydromorphological modifications are caused by the construction of dams, embankments, carrying out channelization and flow regulation [3].

In Poland in 2018, 87\% of rivers and dammed reservoirs did not achieve good ecological status. On the other hand, assessment of the hydromorphological status carried out in 2018 for 998 out of 4586 river water bodies showed that $31 \%$ of the evaluated waters have high status [4]. In comparison to western EU countries Poland is experienced a delay in the occurrence of the "channelization trend", which is a consequence of limited resources available for this purpose in the past. As a result the hydromorphological condition of rivers is relatively good [5]. Still, rivers in Poland have to cope with 
human induced changes, degradation of hydromorphology and mismanagement. The disappearance of multi-thread channels of Polish Carpathian rivers and a $42 \%$ reduction in total anabranch length of the Narew lowland river in the twentieth century is one of many examples that this problem exists [6,7]. An example of inadequate management is the current practice of carrying out of inadequate maintenance works, which does not always meet the standards of the Water Framework Directive (WFD) [2]. Many hydrotechnical investments are carried out under the name of "reconstruction", "upkeep" or "renovation", while in fact, having character of a regulation and channelization of a river [8]. A report prepared by WWF (World Wide Fund for Nature) analyzed river maintenance cases in Poland and concluded that all of them did not foster the achievement of the objectives of the WFD; their implementation was not justified, their results might be counterproductive (flood protection) [9]. Maintenance works were carried out with outdated methods, incompatible with good practices and often excessively expensive technical solutions and some of the actions should be classified as river regulation. Many of these investments led to the destruction of valuable Natura 2000 habitats and/or protected species causing environmental damage. Moreover, maintenance works are usually carried out without the knowledge and control of the authorities directly responsible for the environment, as well as without public participation $[9,10]$. Therefore, the degradation of river ecosystems has rapidly accelerated, directly influencing fish fauna.

The Polish Water Law Act states that the aim of the regulation of natural watercourses is to improve the conditions of water use; it consists of actions that shape the longitudinal and transverse profile, as well as the horizontal layout of the river [11]. According to the law, the regulation of rivers is not a water maintenance activity. Regulation works can be carried out only after obtaining a number of approvals, and the administrative process is very long.

According to the definition given in the Water Law Act [11], the maintenance of inland surface waters should consist of preserving the state of the river bottom or shores and carrying out maintenance of the existing hydro technical structures. These include, cutting of plants from the river bed and shores; removal of floating plants and plants establishing a root system in the river bottom; cutting of trees and bushes growing on the bottom and shores; removal of natural and man-made obstacles; backfilling of shore and bottom erosion; removing blockages, demolition or modification of beaver dams. At the same time, it is forbidden to destroy or damage the shores of inland surface waters. The document states that river maintenance must not violate environmental objectives, existing good water status and conditions resulting from water protection. The maintenance works do not required to obtain a permission from other authorities. Yet, regular dredging and removal of macrophytes strongly disagrees with the global need to preserve river biodiversity. It affects the cover places, which exists in a natural or near a natural river, offering a shelter for various species, which help keep water bodies intact for the benefit of society [12].

River restoration is a tool for repairing damage to the water environment [13]. It includes a variety of modifications of river channels and adjacent riparian zones and floodplains. The goal of these modifications is to improve the hydrologic, geomorphic, and/or ecological processes within a degraded catchment and replace lost, damaged, or compromised components of the natural system [14,15]. It was documented that, in the USA, common river restoration goals, include esthetics/recreation/education; bank stabilization; channel reconfiguration (includes meander restoration and in-channel structures that alter the thalweg); dam removal/retrofit; fish passage; floodplain reconnection; flow modification (releases from impoundments and constructed flow regulators); instream habitat improvement (alter structural complexity); instream species management (addition or translocation of animal and plant native species and/or removal of exotic species); land acquisition (obtain streamside land for the purpose of preservation or removal of impacting agents and/or to facilitate future restoration projects).

Restoration measures can improve the morphological quality of the reach, but the degree of improvement depends on many features, such as the initial morphological conditions, the length of the restored section in relation to the river length, and on the type of intervention [16]. River restoration actions need clearly defined, realistic, multiple-scaled and evaluable goals $[17,18]$. Often it is carried 
out with the use of standard solutions and without verification of the final result $[9,14]$. According to Palmer et al. [19] almost half of the river restoration projects were not controlled for effectiveness. Numerous studies have drawn attention to the need to assess the ecological effectiveness of restoration measures [16,19-22].

The number of aquatic ecosystems damaged by regulation and maintenance is increasing every year. Institutions carrying out river maintenance assure of the neutrality of their activities, while environmental organizations and scientists do not share the same opinion [9]. The discussion focuses on the negative impact on the aquatic ecosystems of river regulation, often omitting maintenance works, which due to legal circumstances, have similar consequences. In response to the emerging situation, guidebooks were created [23], including rules for the execution of maintenance works with respect for the environment and proposals for possible legislative changes. Theses catalogues are based on practical experience and expert judgement.

There is no clear determination on how much the maintenance works degrade river habitats and biodiversity. We assume that restoration improves habitat, but the question how much closer it bring the habitat to target remains open. Lack of clearly defined benchmarks and ecologically focused planning tools causes undesired effects. Hence, there is a need to develop and use appropriate tools [24].

One of the undesirable, long-lasting, form of intervention in river ecosystems is changing the structure of the habitat of fish community. Therefore, it is necessary to use planning tools that take into account the biology of aquatic community. Supporting different life stage requirements of fish species such as reproduction, juvenile growth or feeding habitats requires a combination of different habitat restoration measures, which are appropriately placed and interconnected with each other [25]. Sophisticated management of fish habitats is also important under projected conditions of climate change [26,27].

Habitat simulation techniques offer a good option for river restoration and maintenance planning. They give the possibility to assess the condition of habitats for fish and predict their distribution at various scenarios. One of the advanced tools for this purpose is the Mesohabitat Simulation System (MesoHABSIM) method [28]. It is an effective technique for quantitative estimation of potential changes in the habitats of fish community in rivers, resulting from hydromorphological transformations. It uses on-the-ground habitat mapping and a computer model (Sim-Stream software), that predicts the quantity of habitat for aquatic communities. MesoHABSIM model is used for planning and evaluation restoration works because it can quantitatively assess impacts of such works and their effectiveness. The technique is applied this study to answered the above mentioned questions by simulating maintenance and river restoration works on the example of the Swider River.

\section{Materials and Methods}

\subsection{Swider River}

The Swider River is an orographic right shore tributary of the Vistula River and discharges into it near the town of Otwock ( $85.5 \mathrm{~m}$ above sea level). It is located in the central part of Poland, south-east of Warsaw (the capital of Poland). The length of the river is $99.7 \mathrm{~km}$ (according to the Institute of Meteorology and Water Management) and the watershed area is $1161 \mathrm{~km}^{2}$ (Figure 1). The average slope is $115 \mathrm{~cm} / \mathrm{km}$. The river velocity ranges from 0.3 to $0.5 \mathrm{~m} / \mathrm{s}$. Average annual flow is approximately $5.4 \mathrm{~m}^{3} / \mathrm{s}$. The Swider River has nine tributaries [29]. 


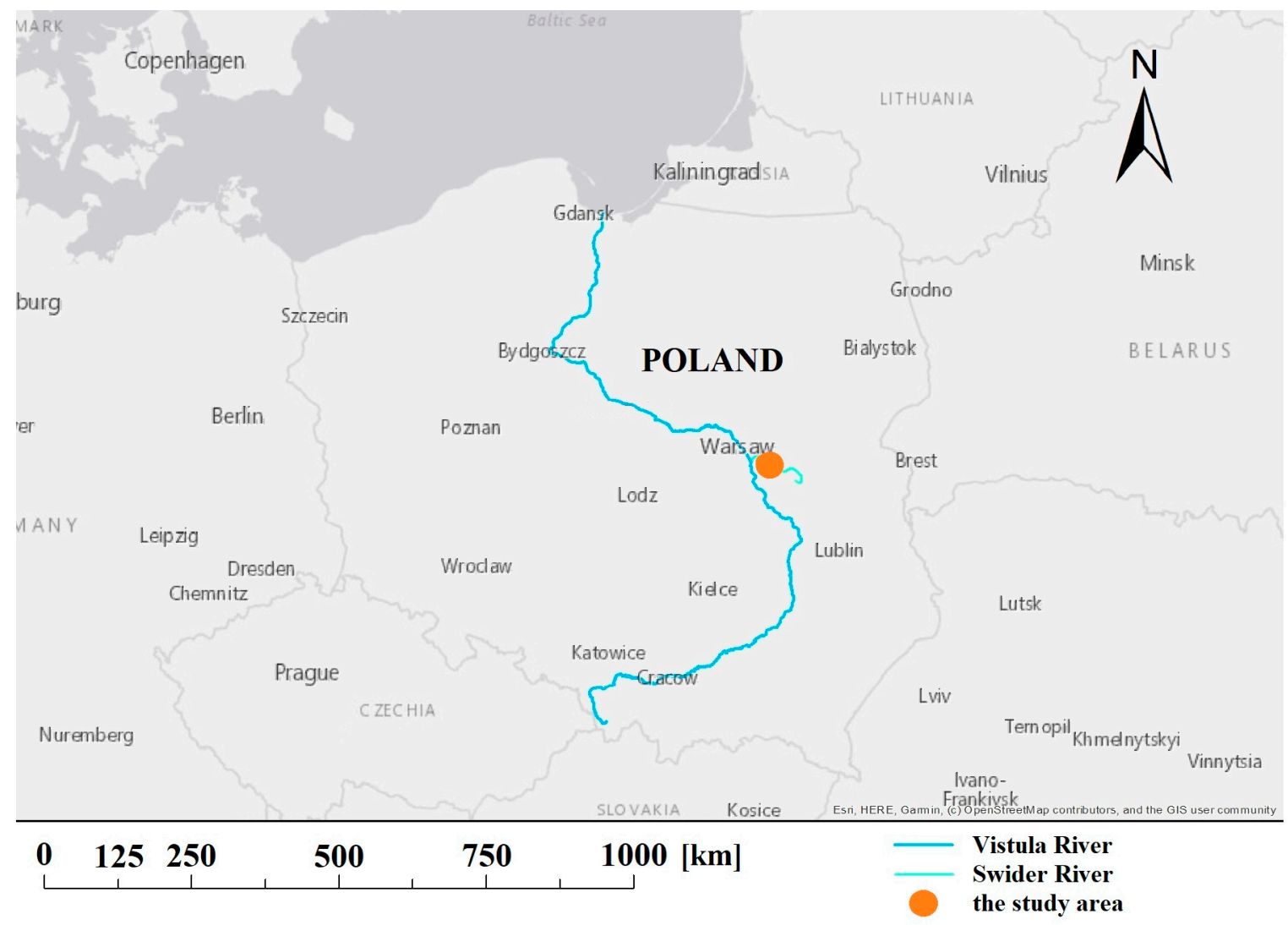

Figure 1. Location of the Swider River in Poland.

The catchment area is dominated by glacial sands and till clay. Fragments of the river, are straightened and regulated. In the upper reaches, the width of the river varies between 2 and $4 \mathrm{~m}$, and the depth between $0.7-1.5 \mathrm{~m}$. A little lower it has a width between 7 and $10 \mathrm{~m}$ and a maximum depth of 1.3-1.5 m. The width of the Swider River in the middle and lower section is 10-25 m, while the maximum depth is $1.5-2.0 \mathrm{~m}$. The areas at the mouth of the river are extensive waterlogged meadows. Here, the width of the river significantly exceeds $25 \mathrm{~m}$ and the depths are small (about $1 \mathrm{~m}$ ), only occasionally reaching $1.5-2.0 \mathrm{~m}$. The land cover in the catchment constitutes of meadows and fields $(76 \%)$, forests $(23 \%)$, and urban areas cover only $1 \%$ of the surface. The Swider Nature Reserve includes $41 \mathrm{~km}$ of the river [29]. The central and lower section of Swider is mostly unregulated and almost natural [30].

Currently on the Swider River there are flap weirs, weirs and bridge-weirs. Some of these weirs significantly limit the migration of fish upstream of the river. Moreover, most probably numerous water barriers and obstacles are not included in the census. This is especially true for small tributaries, which play an important role in connection with the restitution programme of salmonids [30].

\subsection{Hydromorphological and Habitat Assessment}

In order to assess the impact of maintenance and river restoration works on fish communities, hydromorphological maps and criteria for habitat selection by endemic fish species were developed. This allowed the quality and quantity to be calculated for suitable habitats of these species MesoHABSIM model [28,31,32].

In order to examine the physical parameters of the riverbed, cartography was carried out on an approximately $1000 \mathrm{~m}$ representative section of the river (from $\mathrm{km} 83.4$ to $\mathrm{km} 84.4$; not subjected to maintenance work, classified as close to nature). The section was divided into hydromorphological units (HMUs). During the field campaign, the HMUs were classified as: glide (a section of the river relatively wide, shallow with a slower current and an even bottom); run (most common for 
lowland rivers, usually occurs along the shore, carrying the main current of the river, thus, being most often the deepest hydromorphological unit); riffle (a section with small depths, fast current and with characteristic, dense "wrinkles" on the water surface); backwater (a place not belonging to the mainstream, located on the side of the riverbed, the movement of water here is unnoticeable, such a place can be created by woody debris jam); plunge pool (a place where the water whirls due to a fall); ruffle (a unit very similar to riffle, but here the velocities are lower and the "wrinkles" are bigger and rarer) [28]. Data on reference conditions was obtained in September 2014 during a flow rate of $1.3 \mathrm{~m}^{3} / \mathrm{s}$ (qualified as low) [33]. HMU areas were drawn as polygons in the ArcPad program onto digital orthophotomaps. The polygons were divided into hydraulic zones and described with seven representative measurement points per HMU. The next steps included measuring the depth and water velocity and flow for each of the points and collecting information about the bottom substrate (Figure 2). Each HMU was also characterized in terms of potential shelters for fish community (underwater and overhanging vegetation, shading, stones, shoreline cuttings, shore shallows, woody debris, shore reinforcement estimated as present/abundant/absent).

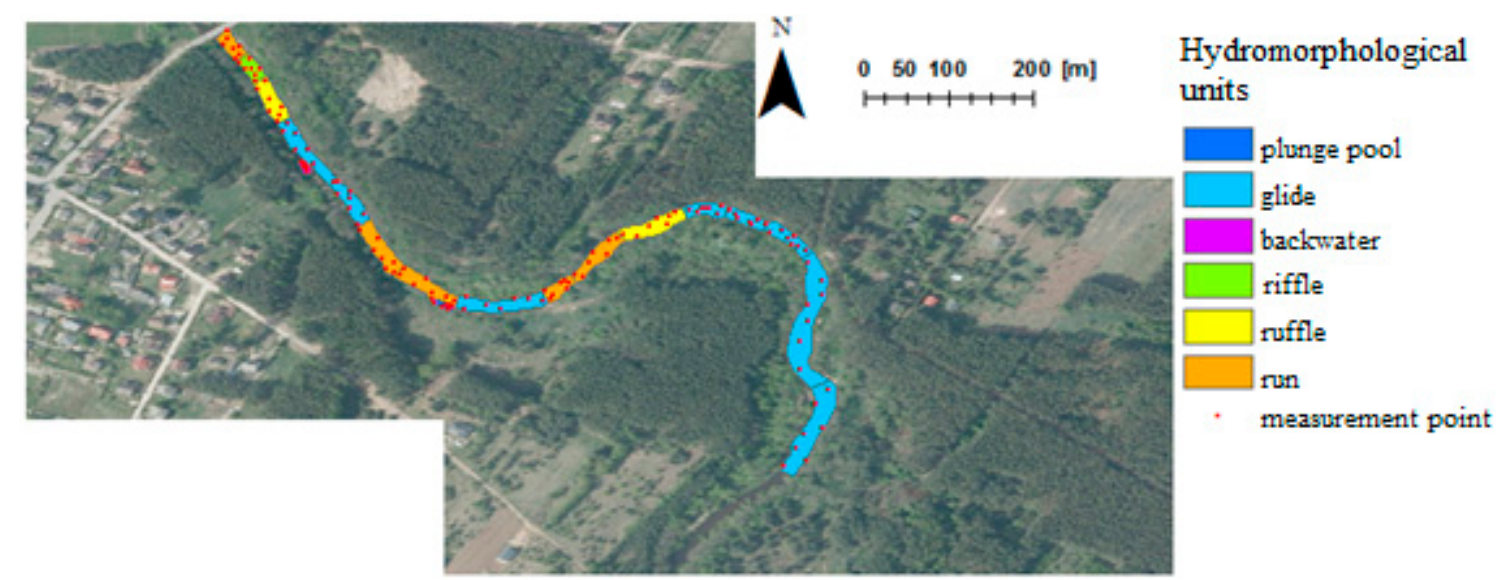

Figure 2. Specified hydromorphological units and measurement points obtained after field studies on the analyzed section of the Swider River (reference conditions).

Unpublished research carried out by the S. Sakowicz Institute of Inland Fisheries branch in Olsztyn allowed to prepare a data base of the most common fish in the studied river section (SSIFI unpub.). On the basis of the preferred living conditions, the fish species were classified into ecological groups (habitat use guilds) [34]. Information on habitat conditions required for these guilds is presented in Table 1.

The criteria in Table 1 outline the habitat suitability of each mapped HMU. Some of the attributes are considered critical and if they were not met, the habitat is estimated as unsuitable.

Where less than four out of five above conditions are met, the habitat was defined as unsuitable. In practice, this means that the guild occurs there rarely or not at all. If four or more conditions are met, the habitat is classified as suitable, which means that the guild is probably there. If the maximum number of conditions (five) is met, the habitat is considered optimal and all conditions are favorable for the guild to occur in the analyzed area. The sums of unsuitable, suitable and optimal HMU areas define habitat usability structure for the site at measured flow. The calculations were conducted using Excel spreadsheet. 
Table 1. Fish guilds and habitat requirements.

\begin{tabular}{|c|c|c|c|c|c|c|}
\hline Fish Guild & Species & $\begin{array}{c}\text { Water } \\
\text { Depth }[\mathrm{m}] *\end{array}$ & $\begin{array}{l}\text { Water Velocity } \\
{[\mathrm{m} / \mathrm{s}]^{*}}\end{array}$ & Type of Substrate ** & $\begin{array}{l}\text { Hydromorphological } \\
\text { Unit }\end{array}$ & Cover $* * * *$ \\
\hline $\begin{array}{l}\text { rheophile sand and } \\
\text { gravel }\end{array}$ & $\begin{array}{l}\text { Lota Lota, Barbatula } \\
\text { barbatula, Leuciscus } \\
\text { leuciscus, Gobio gobio, } \\
\text { Cobitis taenia }\end{array}$ & $0.2-2.5$ & $0.1-0.7$ & $\begin{array}{c}\text { small }(2-6 \mathrm{~cm}) \text { and medium } \\
(6-20 \mathrm{~cm}) \text { stones, sand, fine } \\
\text { gravel }\end{array}$ & glide, run, backwater & $\begin{array}{l}\text { shallows near the shore, } \\
\text { submerged vegetation, woody } \\
\text { debris, eroded banks }\end{array}$ \\
\hline $\begin{array}{l}\text { associated with } \\
\text { vegetation }\end{array}$ & $\begin{array}{l}\text { Pungitius pungitius, } \\
\text { Gasterosteus aculeatus, } \\
\text { Leuciscus idus, Esox } \\
\text { lucius }\end{array}$ & $0.2-2$ & $0-0.5$ & sand, silt, plant residues & glide, run, backwater & $\begin{array}{l}\text { submerged vegetation, woody } \\
\text { debris, eroded banks }\end{array}$ \\
\hline $\begin{array}{l}\text { sand and silt bottom } \\
\text { feeders }\end{array}$ & $\begin{array}{c}\text { Abramis brama, Blicca } \\
\text { bjoerkna }\end{array}$ & $0.2-4$ & $0-0.5$ & sand, silt & run, pool, backwater & $\begin{array}{l}\text { submerged vegetation, woody } \\
\text { debris, eroded banks }\end{array}$ \\
\hline generalists & $\begin{array}{l}\text { Perca fluviatilis, } \\
\text { Rutilus rutilus }\end{array}$ & $0.2-2$ & $0-0.5$ & $\begin{array}{l}\text { sand, silt, fine gravel, plant } \\
\text { residues }\end{array}$ & $\begin{array}{l}\text { run, pool, glide, } \\
\text { backwater }\end{array}$ & $\begin{array}{c}\text { submerged vegetation, woody } \\
\text { debris, eroded banks }\end{array}$ \\
\hline midwater & Alburnus alburnus & $0.5-4$ & $0.1-0.7$ & sand, mud, fine gravel & run, pool, backwater & none \\
\hline lamprey larvae & $\begin{array}{c}\text { Lampetra planeri, } \\
\text { Eudontomyzon mariae }\end{array}$ & $0.1-0.5$ & $0.1-0.3$ & $\begin{array}{l}\text { sand, sludge, organic } \\
\text { residues }\end{array}$ & $\begin{array}{l}\text { run, pool, glide, } \\
\text { backwater }\end{array}$ & shallows near the shore \\
\hline
\end{tabular}

${ }^{*}$ more than $50 \%$ of the measurement points within the estimated range. ${ }^{* *}$ more than $50 \%$ of the measurement points. ${ }^{* * *}$ used by the guild. ${ }^{* * * *}$ present or abundant. 


\subsection{Simulations}

\subsubsection{Maintanance Works}

In order to analyze the impact of typical maintenance works, carried out on Polish rivers [8], the following actions were simulated:

- deepening of the riverbed and removal of the bottom substrate (alluvia from the bottom of the river) to a depth of $0.3-0.5 \mathrm{~m}$;

- deploying only sand (bottom substrate) along the entire section undergoing maintenance works;

- $\quad$ increasing the capacity of the riverbed-removing all obstacles such as stones, branches, fallen trunks, islands;

- $\quad$ increasing the width of the riverbed;

- clearing and mowing the banks at a distance of $2 \mathrm{~m}$ from the riverbed (in order to widen the riverbed);

- $\quad$ armoring the pool slope on eroded banks with riprap. Stone banks are used for the purpose of creating a sunken or partially exposed channel base or the bottom of the riverbed. It is then necessary to align the stone to the designed profile and fill the free spaces [35].

To simulate the above mentioned works, the analyzed river section was divided into HMUs consisting of runs (on relatively straight sections) and pools (where the riverbed bends). Consequently the variability of depth and velocity was reduced and river bottom substrate limited to sand and stones. Woody debris and other cover was removed from the model (Table 2, Figure 3).

Table 2. Assumed parameter ranges for simulated maintenance works on the Swider River.

\begin{tabular}{|c|c|c|}
\hline Hydromorphological Unit & Run & Pool \\
\hline depth [m] & $0.5-1$ & $0.7-1.3$ \\
\hline width $[\mathrm{m}]$ & \multicolumn{2}{|c|}{$15-18$} \\
\hline velocity (mean) [m/s] & $0.3-0.4$ & $0.25-0.35$ \\
\hline benthic substrate & \multicolumn{2}{|c|}{ sand } \\
\hline cover & - & stones \\
\hline
\end{tabular}

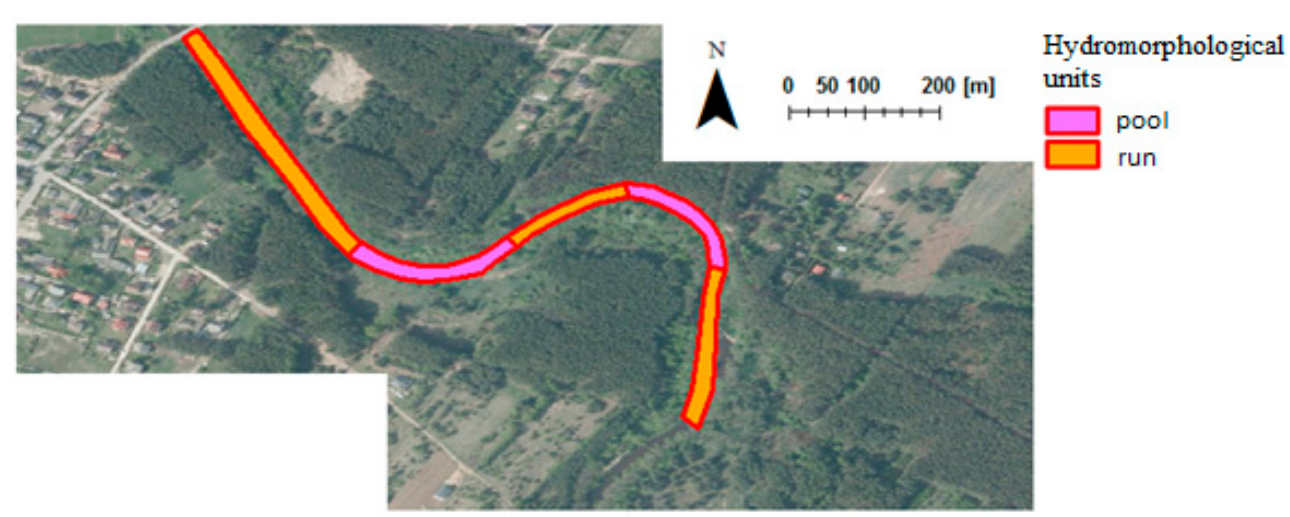

Figure 3. Hydromorphological units obtained after simulating maintenance works on the analyzed section of the Swider River.

\subsubsection{River Restoration}

The main assumption of the river restoration simulation was that these activities were carried out by a contractor who did not know what the examined section of the river looked like before the maintenance works. The simulated river restoration was not conducted on the basis of historical maps, because in practice, such maps are often unavailable. It was presumed that the contractor considered the "maintained" river to be the initial state. River restoration was carried out following a 
good practice manual [13]. The assumptions for the river restoration works are presented in Table 3. In order to avoid hydraulic errors, the values of water depth and velocity have been compared with the data obtained during measurements on the river. Changes in the riverbed (rocks at the bottom of the riffle, tree seedlings on the river banks, riprap replaced with wicker, deflectors as stone prisms) of the examined section concerning the distribution of HMUs are shown on the map (Figure 4.).

Table 3. Assumed parameter ranges for the simulated river restoration of the Swider River.

\begin{tabular}{cccccc}
\hline Characteristics & \multicolumn{5}{c}{ Parameters } \\
\hline Hydromorphological Unit & Run & Fast Run & Pool & Riffle & Backwater \\
\hline $\begin{array}{c}\text { depth [m] } \\
\text { width [m] }\end{array}$ & $0.6-0.9$ & $0.5-1.1$ & $0.5-1.5$ & $0.2-0.5$ & $0.05-0.5$ \\
$\begin{array}{c}\text { velocity (mean) [m/s] } \\
\text { benthic substrate } \\
\text { cover }\end{array}$ & $0.25-0.35$ & $\begin{array}{c}0.3-0.7 \\
\text { sand }\end{array}$ & $0.1-0.2$ & $\begin{array}{c}0.15-0.4 \\
\text { medium stones }\end{array}$ & $\begin{array}{c}\text { silt } \\
\text { Shading }\end{array}$ \\
\hline
\end{tabular}

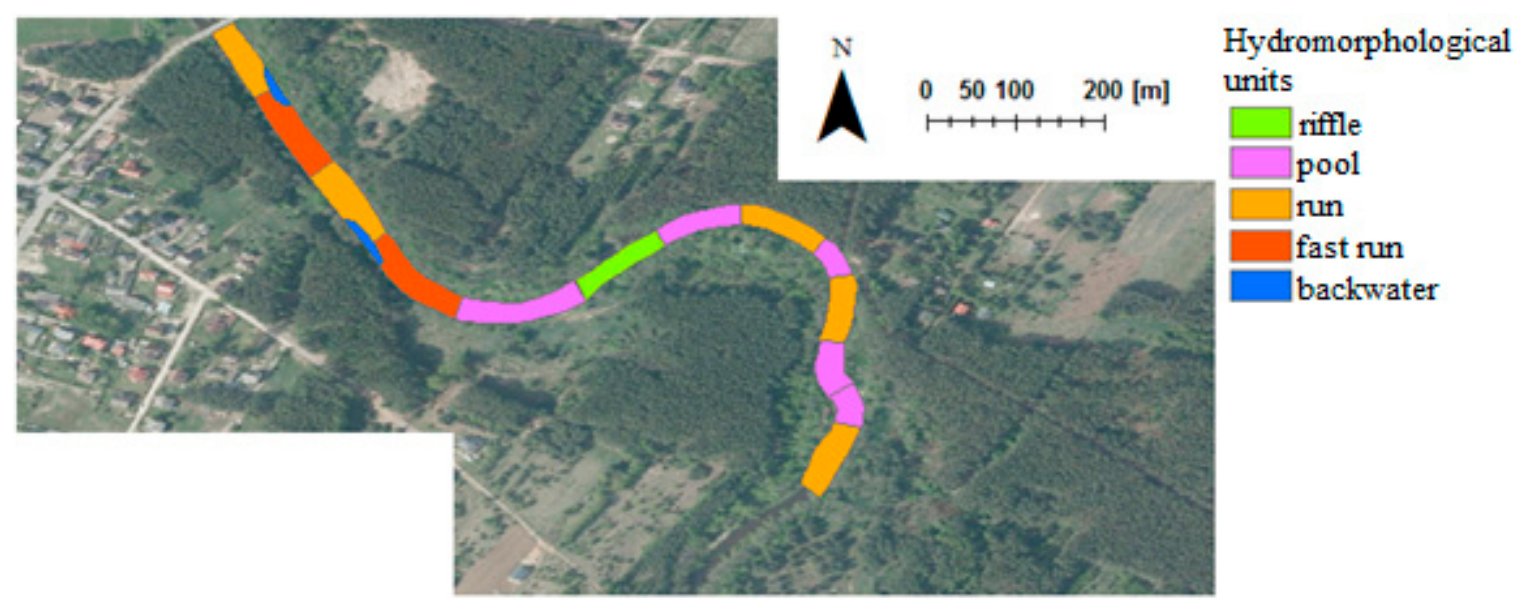

Figure 4. Hydromorphological units obtained after simulating river restoration of the analyzed section of the Swider River.

\subsubsection{Ask the Fish (ATF) Scenario}

On the basis of a comparison of the analyzed fish guilds habitats structure in the reference conditions and after maintenance works, habitats that appeared in deficit or surplus and the guilds belonging to them were identified. From the analysis of conditional habitat selection criteria for guilds (Table 1), the attributes of habitats responsible for these changes were extracted, e.g., area of backwaters being too small or a lack of woody debris. The selected attributes were adjusted by decreasing or increasing their number in the maintenance model. Corrections were made incrementally using affinity index [36] as a metric of structure similarity (see below). The purpose was to create a scenario with HMUs most suitable for the fish guilds.

In order to restore the lost habitats, backwaters and shallows near the shore (supporting lamprey larvae) were created. To increase the amount of habitat for rheophilic sand and gravel species and reduce the amount of habitat for sand and silt bottom feeders, the bottom surface with rock substrate was increased (medium stones) and small stones and gravel were added. In addition, to improve the habitat quality for rheophilic sandy and gravel, places with wood debris were added.

\subsubsection{Metrics Used}

An effective habitat of river channel area was calculated for each guild, for each conditions. It is calculated as sum of suitable and optimal habitats weighted by 0.25 and 0.75 respectively using 
Excel spreadsheet. The weighting factors are introduced to assure high contribution of the optimal habitat [28].

In order to compare changes in fish habitats after maintenance works, river restoration and for the ATF scenario affinity index [36] was used, which is calculated according to the formula below,

$$
I_{p}=1-0.5 \sum\left|P_{1}-P_{2}\right|
$$

where: $I_{p}$ —affinity index [\%], $P_{1}$-relative area of effective habitat for a given fish community species under reference conditions [\%], $P_{2}$-relative area of effective habitat for a given fish community species under conditions after maintenance/river restoration works/ATF scenario [\%].

\section{Results}

The analyzed Swider river section was divided into eighteen HMUs for reference conditions, five HMUs for maintenance works simulation and fifteen HMUs for river restoration simulation. Figure 5 shows the number of unsuitable, suitable and optimal habitats for the analyzed guilds before and after maintenance works and after a standard river restoration.

Under reference conditions in the analyzed section of the river, the four guilds had suitable habitats (approximately $85 \%$ of the area of these habitats belonged to generalists and rheophile sandy and gravel guild), while the midwater guild most probably did not exist under these hydrological conditions ( $100 \%$ of the area of the habitat is unsuitable).

The results for the river after simulated maintenance works show that none of the fish guilds have optimal habitats available. For sand and silt bottom feeders and generalists guilds all the habitats were suitable, while for lamprey larvae, midwater and associated with vegetation guilds all the habitats were unsuitable.

Under the conditions of simulated river restoration none of the fish guilds have available optimal habitats, three guilds (lamprey larvae, midwater, associated with vegetation) will have only unsuitable habitats. The remaining three guilds (sand and silt bottom feeders, generalists, rheophile sandy and gravel) will have suitable and unsuitable habitats.

The size of the effective habitat for each of the guilds in the analyzed river section for reference conditions and three scenarios are shown in Figure 6. After the maintenance works, the effective habitat area increased almost 2.5 times for the sand and silt bottom feeders and significantly decreased for rheophile sandy and gravel (by 11.6\%). River restoration (compared to conditions after maintenance works) led to a slight increase in the number of habitats for sand and silt bottom feeders and generalists (each by 1.7\%), while it decreased the number of habitats for rheophilic sandy and gravel (by 3.3\%). In the ATF scenario (compared to conditions after maintenance works) the amount of bottom-sand-silty habitat decreased almost twofold (by 16.9\%), it remained almost the same for generalists, and slightly increased for rheophilic sandy and gravel (by 6.6\%).

The affinity index between the structure of habitats under reference conditions and those after simulated maintenance work is $76.5 \%$. The distribution of habitats caused by river restoration is similar to that under reference conditions in $73.2 \%$. The similarity between the ATF scenario and the reference conditions is $93.1 \%$ (Figure 6). 


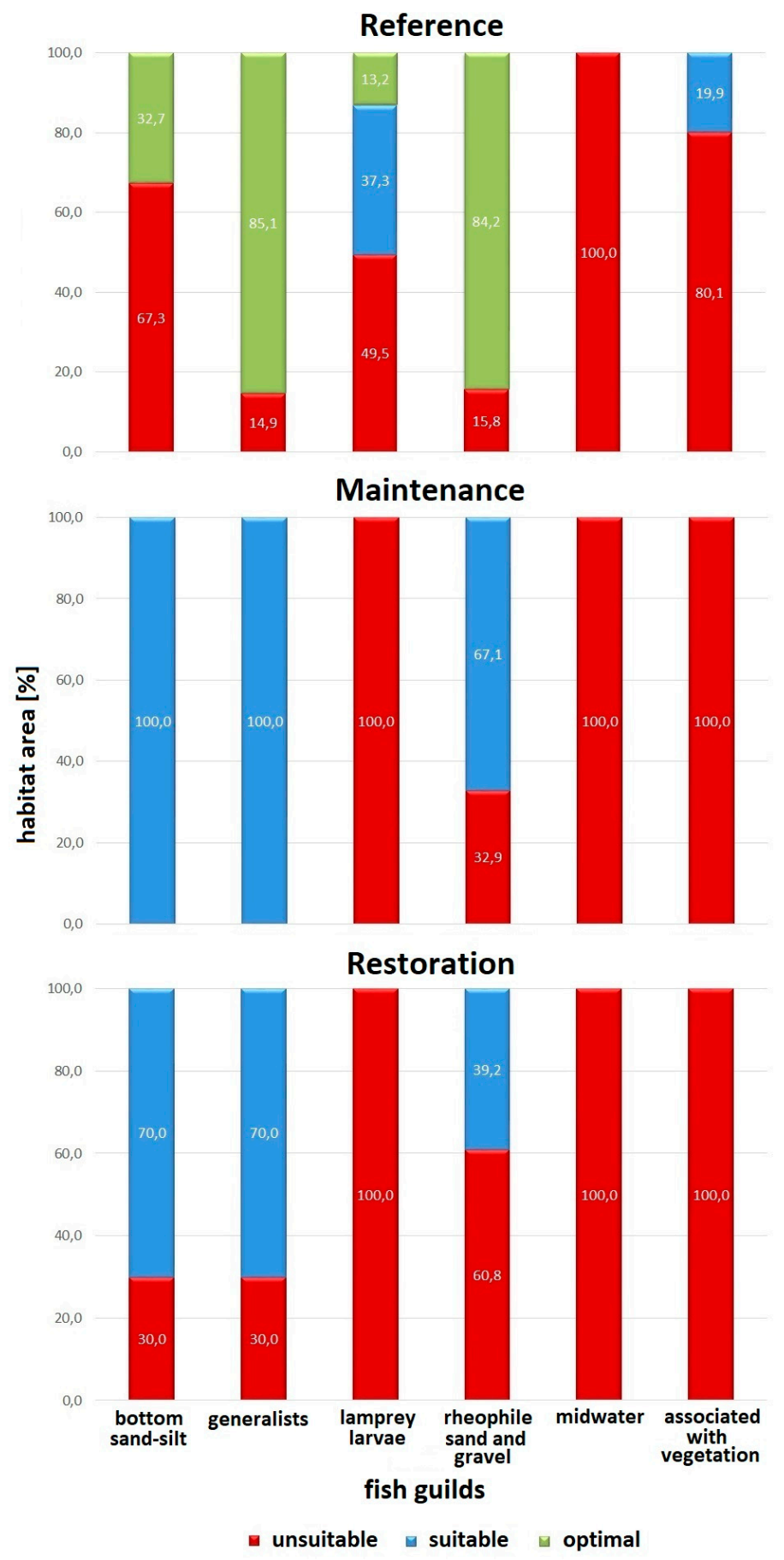

Figure 5. Habitat usability for fish guilds for the reference conditions, after simulated maintenance and restoration works on the Swider river section. 


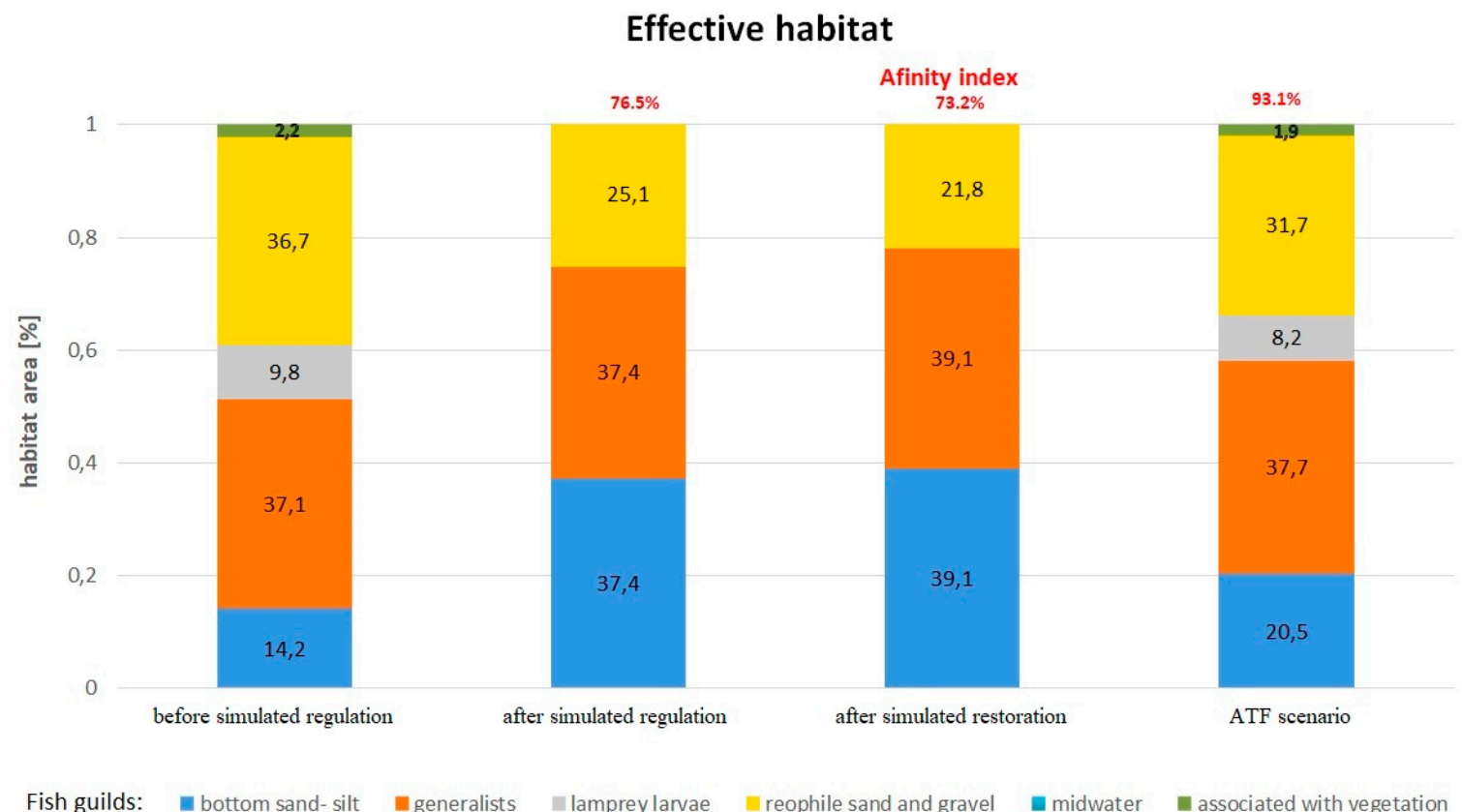

Figure 6. Effective habitat area and affinity index for fish guilds on the Swider river section for reference conditions and simulated maintenance works, river restoration and ATF scenario.

\section{Discussion}

This study suggests that alterations in the hydromorphology of the river lead to changes in the distribution of habitats what is also confirmed by the results of other research $[14,19,37]$. The presence of an adequate proportion of habitats is necessary for stable development of species and their lack creates conditions limiting the survival of organisms. Maintenance works can lead to changes in habitat structure, creating deficits or excesses of habitats for individual guilds. The structure of the fish community changes, such that may upset the balance and ecological dependencies. Therefore, it is important that the restoration activities are carefully planned and adapted to the requirements of existing fish species.

The MesoHABSIM model offers a useful planning tool as it allows to define the specific habitat needs of the species present and to select a catalog of appropriate actions. Such a planning method has already been used in global research allowing for more effective use of resources [32,38]. With the help of the MesoHABSIM habitat model it is possible to define more precisely the goals of river restoration, by analyzing for which guilds there is an abundance of available habitats and for which there are too few. Prior to a planned river restoration is carried out, it is beneficial to simulate the changes and determine whether a suitable amount of optimal and suitable habitats can be restored. Although these simulations are approximations, it enables the assessment of the impacts of applied actions on fish communities and thus plan better solutions. It is a significant saving of work time and costs, but most importantly, it gives possibility to obtain and verify the expected results [24,39].

Swider river has an unregulated and almost natural character and serves as a good testing ground for simulations of changes in the river hydromorphology. The results of the simulations that were carried out show that the maintenance works on the examined section of the Swider River could devastate the water ecosystem, in terms of living conditions for two guilds (lamprey larvae and associated with vegetation) (Figure 5.). It should be noted that the species Lampetra planeri and Eudontomyzon mariae, belonging to the Lamprey larvae guild, are under protection. Furthermore, entire optimal habitats for all guilds have disappeared. Apart from the habitat for the midwater guild, which remains the same as in the reference conditions (unsuitable), the habitat status for all guilds has deteriorated dramatically due to simulated maintenance works. These results correspond well with literature information. Baczyk et al. [12] carried out a literature review and meta-analysis of 203 papers 
written by authors from 33 countries (first authors), dealing with the impact of dredging works on water ecosystems. The results show that $96 \%$ of the analyzed papers indicated negative responses of aquatic ecosystems (including fish community) to river maintenance works.

In the second experiment, despite the introduction of standard river restoration works, the condition of habitats for three guilds has further deteriorated. In comparison to maintenance works simulation the proportion of unsuitable habitats for sand and silt bottom feeders, generalists and rheophile sandy and gravel bottom guilds has significantly increased. Nothing has changed for the other three guilds for which the unsuitable habitats still constitute $100 \%$ of the wetted area. Comparing the effect of river restoration works with reference conditions, the most important observation is the total disappearance of optimal habitats. Hence, the applied river restoration measures not only did not restore these habitats, but there was a general increase in the number of unsuitable habitats. This is due to the fact that river restoration would be planned and performed, according to accepted templates, without considering the habitat requirements of occurring fish. The affinity index is $3.3 \%$ lower for river restoration than it is for maintenance works, which makes for a surprising conclusion that the results of both types of actions are similar.

The maintenance of habitat target fish communities as a restoration target is an important part in the design and evaluation of river restoration [40]. The ATF method takes into consideration fish guilds needs and is a simulation of an advanced river restoration. Our example facilitated the restoration of habitats for two guilds (lamprey larvae and fish associated with vegetation). The habitats for the other guilds assumed proportions very close to those in the reference conditions. The improvement of habitat availability achieved in this scenario, in comparison to reference conditions is significantly better than in other two scenarios.

In this study, the standard "by-the-book" river restoration did not achieve the habitat structure closer to the reference conditions. These differences emphasize that it is not advised to use normative measures but each river should be approached type specific also taking into account the expected structure of native fish community.

Author Contributions: Conceptualization, K.S. and P.P.; methodology, P.P.; software, K.S. and P.P.; validation, P.P.; formal analysis, K.S. and P.P.; investigation, K.S.; resources, K.S. and P.P.; data curation, K.S. and P.P.; writing-original draft preparation, K.S. and P.P.; writing-review and editing, K.S. and P.P.; visualization, K.S.; supervision, P.P.; project administration, P.P.; funding acquisition, P.P. Both authors have read and agreed to the published version of the manuscript.

Funding: Funding for this research was provided by subsididy of Polish Ministry of Science and Education.

Acknowledgments: Thanks are due to Joanna O'Keeffe, for her help in touching up the manuscript, selecting literature and many helpful suggestions. Many thanks go also to Zbigniew Popek, Katarzyna Celejewska of Warsaw University of Life Science for help in data collection and advise as well as colleagues from Stanislaw Sakowicz Inland Fisheries Institute: Janusz Ligięza, Pawel Buras, Pawel Prus, Jacek Szlakowski, Wieslaw Wisniewolski, Irena Borzęcka, Mikolaj Adamczyk.

Conflicts of Interest: The authors declare no conflict of interest.

\section{References}

1. European Union Council Directive 91/676/EEC of 12 December 1991 Concerning the Protection of Waters against Pollution Caused by Nitrates from Agricultural Sources. Available online: https:/eur-lex.europa.eu/ legal-content/EN/TXT/?uri=LEGISSUM:128013 (accessed on 19 August 2020).

2. European Union Directive 2000/60/EC of the European Parliament and of the Council of 23 October 2000 Establishing a Framework for Community Action in the Field of Water Policy. Available online: https:/eur-lex.europa.eu/legal-content/EN/TXT/?qid=1597832816764\&uri=CELEX:32000L0060 (accessed on 19 August 2020).

3. European Environment Agency. European Waters-Assessment of Status and Pressures 2018; European Environment Agency: Copenhagen, Denmark, 2018. 
4. Kolada, A.; Pasztaleniec, A.; Bielczyńska, A.; Ochocka, A.; Kutyła, S.; Izydorczyk, K.; Krauze, K.; Biernacki, M.; Zalewska, T.; Kraśniewski, W. Ocena Stanu Rzek, Jezior, Wód Przejściowych i Przybrzeżnych W Latach 2016-2018; Chief Inspectorate of Environmental Protection: Warsaw, Poland, 2019.

5. Lewandowski, P. Polish Investigations on River Hydromorphology. Polish J. Environ. Stud. 2012, 21, 957-965.

6. Hajdukiewicz, H.; Wyżga, B.; Zawiejska, J. Twentieth-century hydromorphological degradation of Polish Carpathian rivers. Quat. Int. 2019, 504, 181-194. [CrossRef]

7. Marcinkowski, P.; Grabowski, R.C.; Okruszko, T. Controls on anastomosis in lowland river systems: Towards process-based solutions to habitat conservation. Sci. Total Environ. 2017, 609, 1544-1555. [CrossRef] [PubMed]

8. Pielech, R.; Kisiel, P. Prace Utrzymaniowe Jako Zagrożenie dla Osiagnięcia Środowiskowych Celów Ramowej Dyrektywy Wodnej Oraz dla Funkcjonowania Sieci Ekologicznej Natura 2000 w Polsce; WWF: Wrocław, Poland, 2010.

9. Jabłońska, E.; Kotkowicz, M.; Manewicz, M.; Nawrocki, P.; Pawlaczyk, P. Podsumowanie i Interpretacja Wyników Raportu Inwentaryzacja oraz Ocena Skutków Przyrodniczych Ingerujacych w Hydromorfologię rzek prac 'Utrzymaniowych' Wykonanych na Ciekach Województw Łódzkiego, Podkarpackiego, Podlaskiego, Małopolskiego, Mazowieckiego; WWF: Warsaw, Poland, 2014.

10. Szałkiewicz, E.; Jusik, S.; Grygoruk, M. Status of and Perspectives on River Restoration in Europe: 310,000 Euros per Hectare of Restored River. Sustainability 2018, 10, 129. [CrossRef]

11. Dz.U.2020.310. Prawo Wodne. Available online: https://isap.sejm.gov.pl/isap.nsf/DocDetails.xsp?id= WDU20200000310 (accessed on 19 August 2020).

12. Bączyk, A.; Wagner, M.; Okruszko, T.; Grygoruk, M. Influence of technical maintenance measures on ecological status of agricultural lowland rivers-Systematic review and implications for river management. Sci. Total Environ. 2018, 627, 189-199. [CrossRef]

13. Żelazo, J.; Zbigniew, P. Podstawy Renaturyzacji Rzek, 2nd ed.; Warsaw University of Life Scienes Publishing House: Warsaw, Poland, 2014; ISBN 978-83-7583-573-1.

14. Wohl, E.; Angermeier, P.L.; Bledsoe, B.; Kondolf, G.M.; MacDonnell, L.; Merritt, D.M.; Palmer, M.A.; Poff, N.L.; Tarboton, D. River restoration. Water Resour. Res. 2005, 41. [CrossRef]

15. Wohl, E.; Lane, S.N.; Wilcox, A.C. The science and practice of river restoration. Water Resour. Res. 2015, 51, 5974-5997. [CrossRef]

16. Belletti, B.; Nardi, L.; Rinaldi, M.; Poppe, M.; Brabec, K.; Bussettini, M.; Comiti, F.; Gielczewski, M.; Golfieri, B.; Hellsten, S.; et al. Assessing Restoration Effects on River Hydromorphology Using the Process-based Morphological Quality Index in Eight European River Reaches. Environ. Manag. 2018, 61, 69-84. [CrossRef]

17. González, E.; Felipe-Lucia, M.R.; Bourgeois, B.; Boz, B.; Nilsson, C.; Palmer, G.; Sher, A.A. Integrative conservation of riparian zones. Biol. Conserv. 2017, 211, 20-29. [CrossRef]

18. Carvalho, L.; Mackay, E.B.; Cardoso, A.C.; Baattrup-Pedersen, A.; Birk, S.; Blackstock, K.L.; Borics, G.; Borja, A.; Feld, C.K.; Ferreira, M.T.; et al. Protecting and restoring Europe's waters: An analysis of the future development needs of the Water Framework Directive. Sci. Total Environ. 2019, 658, 1228-1238. [CrossRef]

19. Palmer, M.A.; Hondula, K.L.; Koch, B.J. Ecological restoration of streams and rivers: Shifting strategies and shifting goals. Annu. Rev. Ecol. Evol. Syst. 2014, 45, 247-269. [CrossRef]

20. Lockwood, J.L.; Pimm, S.L. When does restoration succeed? In Ecological Assembly Rules: Perspectives, Advances, Retreats; Weiher, E., Keddy, P., Eds.; Cambridge University Press: Cambridge, UK, 2004; pp. 363-392, ISBN 0-511-03299-4.

21. Ward, J.V.; Tockner, K.; Uehlinger, U.; Malard, F. Understanding natural patterns and processes in river corridors as the basis for effective river restoration. Regul. Rivers Res. Manag. 2001, 17, 311-323. [CrossRef]

22. Lüderitz, V.; Jüpner, R.; Müller, S.; Feld, C.K. Renaturalization of streams and rivers- the special importance of integrated ecological methods in measurement of success. An example from Saxony-Anhalt (Germany). Limnologica 2004, 34, 249-263. [CrossRef]

23. Biedroń, I.; Dubel, A.; Grygoruk, M.; Pawlaczyk, P.; Prus, P.; Wybraniec, K. Katalog Dobrych Praktyk w Zakresie Robót Hydrotechnicznych i Prac Utrzymaniowych Wraz z Ustaleniem Zasad ich Wdrażania; MGGP: Kraków, Poland, 2018.

24. Parasiewicz, P.; Nestler, J.M.; Poff, N.L.; Goodwin, R.A. Virtual Reference River: A Model for Scientific Discovery and Reconciliation; Ecological Management, Nova Science Publishers: New York, USA, 2011; ISBN 9781604567861. 
25. Pander, J.; Geist, J. The Contribution of Different Restored Habitats to Fish Diversity and Population Development in a Highly Modified River: A Case Study from the River Günz. Water 2018, 10, 1202. [CrossRef]

26. Kundzewicz, Z.W.; Piniewski, M.; Mezghani, A.; Okruszko, T.; Pińskwar, I.; Kardel, I.; Hov, Ø.; Szcześniak, M.; Szwed, M.; Benestad, R.E.; et al. Assessment of climate change and associated impact on selected sectors in Poland. Acta Geophys. 2018, 66, 1509-1523. [CrossRef]

27. O’Keeffe, J.; Piniewski, M.; Szcześniak, M.; Oglęcki, P.; Parasiewicz, P.; Okruszko, T. Index-based analysis of climate change impact on streamflow conditions important for Northern Pike, Chub and Atlantic salmon. Fish. Manag. Ecol. 2019, 26, 474-485. [CrossRef]

28. Parasiewicz, P. The MesoHABSIM model revisited. River Res. Appl. 2007, 23, 893-903. [CrossRef]

29. Jagiełło, J. Jeziorka Świder Wilga Okrzejka oraz ich Dopływy; Interesting Places Publishing House: Warsaw, Poland, 2014; ISBN 9788363424312.

30. Orłow-Gozdowska, Ł. Program Ochrony i Rozwoju Zasobów Wodnych Województwa Mazowieckiego w Zakresie Udrożnienia rzek dla ryb Dwuśrodowiskowych-Projekt; Marshal's Office of Mazowieckie Province: Warsaw, Poland, 2005.

31. Parasiewicz, P.; Rogers, J.N.; Vezza, P.; Gortázar, J.; Seager, T.; Pegg, M.; Wiśniewolski, W.; Comoglio, C. Applications of the MesoHABSIM Simulation Model. In Ecohydraulics; John Wiley \& Sons, Ltd.: Chichester, UK, 2013; pp. 109-124.

32. Parasiewicz, P. Using MesoHABSIM to develop reference habitat template and ecological management scenarios. River Res. Appl. 2007, 23, 924-932. [CrossRef]

33. Suska, K. Ocena Wpływu prac Utrzymaniowych i Renaturyzacyjnych Rzeki Świder na Siedliska ryb z Wykorzystaniem Metody MesoHABSIM. Ph.D. Thesis, Warsaw University, Warsaw, Poland, 2015.

34. Brylińska, M. Ryby Stodkowodne Polski, 3rd ed.; Wydawnictwo Naukowe PWN: Warszawa, Poland, 2000; ISBN 83-01131-00-4.

35. Wołoszyn, J.; Czamara, W.; Eliasiewicz, R.; Krężel, J. Regulacja Rzek i Potoków; Akademia Rolnicza Wrocław: Wrocław, Poland, 1994; ISBN 83-85582-45-2.

36. Novak, M.A.; Bode, R.W. Percent Model Affinity: A New Measure of Macroinvertebrate Community Composition. J. N. Am. Benthol. Soc. 1992, 11, 80-85. [CrossRef]

37. Reid, A.J.; Carlson, A.K.; Creed, I.F.; Eliason, E.J.; Gell, P.A.; Johnson, P.T.J.; Kidd, K.A.; MacCormack, T.J.; Olden, J.D.; Ormerod, S.J.; et al. Emerging threats and persistent conservation challenges for freshwater biodiversity. Biol. Rev. 2019, 94, 849-873. [CrossRef]

38. Spurgeon, J.; Pegg, M.; Parasiewicz, P.; Rogers, J. River-Wide Habitat Availability for Fish Habitat Guilds: Implications for In-Stream Flow Protection. Water 2019, 11, 1132. [CrossRef]

39. Nestler, J.M.; Pompeu, P.S.; Goodwin, R.A.; Smith, D.L.; Silva, L.G.M.; Baigún, C.R.M.; Oldani, N.O. The river machine: A Template for Fish Movement and Habitat, Fluvial Geomorphology, Fluid Dynamics and Biogeochemical Cycling. River Res. Appl. 2012, 28, 490-503. [CrossRef]

40. Bain, M.B.; Meixler, M.S. A Target Fish Community to Guide River Restoration. River Res. Appl. 2008, 24, 453-458. [CrossRef]

Publisher's Note: MDPI stays neutral with regard to jurisdictional claims in published maps and institutional affiliations.

(C) 2020 by the authors. Licensee MDPI, Basel, Switzerland. This article is an open access article distributed under the terms and conditions of the Creative Commons Attribution (CC BY) license (http://creativecommons.org/licenses/by/4.0/). 